\title{
HUBUNGAN PENGETAHUAN DENGAN PERILAKU IBU HAMIL DALAM MENJALANI KEHAMILAN SELAMA MASA PANDEMI COVID-19
}

The Correlation Between Knowledge and Behavior of Pregnant Women in Undergoing Pregnancy During the Covid-19 Pandemic

Mira Rizkia ${ }^{1}$, Mariatul Kiftia ${ }^{1}$, Dara Ardhia ${ }^{1}$, Darmawati $^{1}$, Aida Fitri ${ }^{1}$, dan Nova Fajri ${ }^{2}$

1. Bagian Keperawatan Maternitas, Fakultas Keperawatan Universitas Syiah Kuala Banda Aceh mira.rizkia@unsyiah.ac.id

2. Bagian Keperawatan Anak, Fakultas Keperawatan Universitas Syiah Kuala Banda Aceh

\begin{abstract}
Background: Pregnancy, also known as the gestation phase, is a physiological process experienced by a woman. There are various factors that can influence a mother in undergoing her pregnancy including knowledge and behavior.

Purose: The aim of this study was to determine the correlations between knowledge and behavior of mothers during pregnancy during the Covid-19 pandemic in Aceh.

Method: This is a descriptive explorative research with cross sectional desain. There were 138 pregnant women who were selected as respondents by using the simple random sampling. Data analysis involved the use of the chi-square.

Results: Showed that there was a relationship between knowledge and maternal behavior during pregnancy during the Covid-19 pandemic $(p=.001)$.

Recommendation: Therefore, the knowledge is an important factor for pregnant women because it can affect the mother's behavior during pregnancy. It is hoped that optimal education from health workers for mothers to be able to live their pregnancy in a prosperous manner so that mothers and fetuses remain healthy during the Covid-19 pandemic.
\end{abstract}

Keywords: Knowledge, Behavior, Pragnancy, Covid-19 Pandemic

\begin{abstract}
ABSTRAK
Latar Belakang: Kehamilan merupakan disebut juga fase gestasi merupakan proses fisiologis yang dialami oleh seorang perempuan. Terdapat berbagai faktor yang dapat mempengaruhi ibu dalam menjalani kehamilannya termasuk pengetahuan dan juga perilaku. Tujuan: Penelitian ini adalah untuk melihat hubungan pengetahuan dengan perilaku ibu hamil dalam menjalani kehamilan pada masa pandemi Covid-19 di Aceh.

Metode; Jenis penelitian ini deskriptif explorative dengan pendekatan cross sectional desain. Terdapat $138 \mathrm{ibu}$ hamil yang terpilih sebagai responden dengan metode simple random sampling. Analisa data dilakukan dengan menggunakan uji chi-square.

Hasil: Hasil penelitian menunjukkan bahwa terdapat hubungan antara pengetahuan dengan perilaku ibu dalam menjalani kehamilannya selama masa pandemic Covid-19 ( $p=.001)$.

Kesimpulan: Sehingga dapat disimpulkan bahwa pengetahuan merupakan faktor penting bagi ibu hamil karena dapat mempengaruhi perilaku ibu selama kehamilan. Sehingga sangat diharapkan edukasi yang optimal dari tenaga Kesehatan bagi ibu agar dapat menjalani masa kehamilannya dengan sejahtera sehingga ibu dan janin tetap sehat selama masa pandemi Covid-19.
\end{abstract}

Kata Kunci: Pengetahuan, Perilaku, Ibu Hamil, Pandemi Covid-19. 


\section{PENDAHULUAN}

Coronavirus disease (Covid-19) yang ditemukan pertama kali di Wuhan dengan sebutan novel coronavirus 2019 (2019-nCoV) yang disebabkan oleh virus Severe Acute Respiratory Syndrome Coronavirus-2 (SARS-CoV-2) (WHO, 2020). Di Indonesia angka morbiditas dan mortalitas terus terjadi. Hingga bulan April tahun 2020 angka kematian dikarenakan Covid-19 di Indonesia mencapai jumlah 784 orang dinyatakan meninggal dan 9.771 orang terkonfirmasi positif, dan 1.391 orang dinyatakan smbuh (Kementerian Kesehatan RI., 2020).

Ibu hamil merupakan salah satu kelompok khusus yang rentan terkena virus Covid-19 (Samji, 2020). Selama hamil terjadi penurunan kekebalan parsial, sehingga mengakibatkan ibu hamil lebih rentan terhadap infeksi virus. Perubahan fisiologis dan imunologis yang terjadi sebagai komponen normal kehamilan dapat memiliki efek sistemik yang meningkatkan risiko komplikasi obstetrik dari infeksi pernapasan pada ibu hamil (Khan et al., 2020). Hal ini berisiko terhadap terjadinya komplikasi pada ibu selama kehamilan baik berupa gangguan pernafasan seperti penurunan kapasitas paru dan sistem kardiovaskular seperti terjadinya takikardi (Samji, 2020), bahkan kekurangan nutrisi (Khan et al., 2020).

Hingga saat ini informasi tentang Covid-19 pada kehamilan masih terbatas yang dapat memberikan dampak negatif bagi Kesehatan ibu hamil dalam menjalani kehamilannya pada masa pandemi Covid-19 (Liang \& Acharya, 2020). Karena selama masa pandemi terjadi perubahan yang signifikan pada peayanan Kesehatan terutama ibu hamil. Berdasarkan data dari Kementerian Kesehatan Indonesia (Kemenkes RI) kunjungan pemeriksaan kehamilan juga mengalami penurunan, bahkan hanya $19,2 \%$ posyandu yang masih aktif selama pandemi (Mar'ah, 2020).

Seharusnya ibu hamil memiliki pengetahuan dan pemahaman yang baik tentang cara menjaga diri agar terhindar dari Covid-19. Melalui pengetahaun yang adekuat harapannya ibu juga dapat memiliki sikap dan perilaku yang baik dalam menjalani kehidupannya sehari-hari. Sehingga berdasarkan fenomena tersebut maka penulis tertarik untuk melakukan penelitian tentang hubungan tingkat pengetahuan dengan perilaku ibu hamil dalam menjalani kehamilan di masa pandemi Covid-19.

\section{METODE}

Penelitian ini telah lulus uji etik dari Komite Etik Penelitian Fakultas Keperawatan Universitas Syiah Kuala dengan nomor 113001130420. Penelitian ini bersifat kuantitatif dengan jenis penelitian deskriptif explorative dengan pendekatan cross sectional desain. Sampel penelitian ini berjumlah 138 orang ibu hamil dengan menggunakan metode purposive sampling 
dengan kriteria inklusi ibu hamil trimester satu, dua, dan tiga serta ibu hamil tanpa komplikasi. Dan penelitian ini dilakukan di wilayah Pidie dan Aceh Utara Propinsi Aceh. Proses pengumpulan data dilakukan pada bulan Mei 2020 dengan menggunakan kusioner online. Kemudian Analisa data menggunakan Chi-Square test.

\section{HASIL}

Hasil penelitian diperoleh melalui Analisa univariat dan analisa bivariat serta Chi-Square test. Adapun hasil Analisa univariat dapat dilihat pada table 1 (terlampir). Dapat diketahui bahwa responden berasal dari Aceh Utara berjumlah 50 orang (36,2\%), dan Pidie 88 orang $(63,8 \%)$. Sedangkan usia ibu hamil mayoritas pada kategori dewasa awal yaitu berjumlah 79 orang $(57,2 \%)$. Dan paritas ibu hamil mayoritas dikatagorikan kedalam primipara atau kehamilan pertama yaitu berjumlah 70 orang $(50,7 \%)$.

Kemudian mayoritas tingkat pengetahuan ibu hamil berada pada kategori baik yaitu 70 orang $(50,7 \%)$, sehingga dapat disimpulkan bahwa ibu hamil di Wilayah Pidie dan Aceh Utara memiliki tingkat pengetahuan yang baik terkait kesiapannya dalam menjalani kehamilan di masa pandemi Covid-19 (Tabel 2). Dan terdapat sebagian besar yaitu 82 orang $(59,4 \%)$ ibu hamil di Pidie dan Aceh Utara memiliki perilaku yang baik terkait kesiapannya dalam menjalani kehamilan di masa pandemi Covid-19 (Tabel 3).

Sedangkan pada tabel 4 dapat diketahui bahwa adanya hubungan yang signifikan antara Tingkat pengetahuan dengan perilaku ibu dalam menjalani kehamilan di masa pandemic Covid-19 dengan $p$-value $=0.001$. Dengan level of significance $($ alpha $=5 \%)$ maka pada taraf nyata $5 \%$ dapat dinyatakan bahwa terdapat hubungan antara dua variable tersebut.

\section{PEMBAHASAN}

Hasil penelitian ini menunjukkan bahwa terdapat hubungan yang bermakna antara tingkat pengetahuan dengan perilaku ibu hamil dalam menjalankan kehamilannya selama masa pandemi Covid-19 dengan nilai $p=.001$. Mayoritas tingkat pengetahuan ibu hamil berada pada kategori yang baik $(50,7 \%)$, dan perilaku yang baik $(59,4 \%)$. Hal ini sesuai dengan penelitian yang dilakukan di salah satu Rumah Sakit di Nigeria Utara bahwa tingkat pengetahuan menjadi faktor yang dapat mempengaruhi sikap dan perilaku ibu hamil selama masa pandemi Covid-19 (Anikwe et al., 2020). Hasil penelitian lain juga membuktikan bahwa ibu hamil dengan tingkat pengetahuan yang baik maka memiliki perilaku yang baik selama hamil, sehingga siap untuk menjalankan masa kehamilannya dengan sejahtera (Hoque \& Hoque, 2011). 
Idealnya, pengetahun merupakan hal yang penting bagi ibu selama menjalani kehamilannya terutama terkait masa pandemi Covid-19 (Nwafor et al., 2020). Sebagaimana hasil penelitian yang dilakukan oleh Aniewke dkk (2020), menunjukkan bahwa mayoritas ibu hamil di Nigeria Utara memiliki pengetahuan yang baik (82\%). Namun sedikit berbeda dengan hasil penelitian yang dilakukan di Afrika, bahwa terdapat 60,9\% ibu hamil memiliki pengetahuan yang adekuat tentang cara melindungi diri dari Covid-19 namun dalam praktisnya masih rendah yaitu sekitar 69,7\% (Nwafor et al., 2020).

Kurangnya perilaku ibu hamil dalam menjaga diri dari Covid-19 dapat disebabkan oleh rendahnya tingkat kesadaran diri, kebiasaan yang salah, serta pengaruh dari lingkungan sekitar yang memiliki pola perilaku yang tidak baik (Al-Ateeq \& Al-Rusaiess, 2015). Dan Nwafor et al., (2020), juga menjelaskan bahwa perilaku yang tidak adekuat ini juga disebbakan oleh faktor paritas, dimana ibu grandmultipara memperlihatkan tiga kali perilaku yang lebih buruk dibanding ibu nullipara.

Sumber informasi juga menjadi salah satu faktor lainnya yang berkaitan dengan perolehan pengetahuan dan perubahan perilaku yang baik bagi seseorang (Shing \& Brod, 2016). Karena berdasarkan hasil penelitian Nwafor et al., (2020), terdapat perbedaan antara tingkat pengetahuan ibu hamil yang mendapat edukasi secara formal dan rutin sebanyak enam kali selama hamil memiliki pengetahuan yang lebih baik dibandingkan ibu hamil yang tidak memperoleh informasi secara formal dari tenaga Kesehatan.

Sehingga menurut Khoramabadi (2015), pemberian informasi yang lebih komprehensif bagi ibu hamil selama kunjungan kehamilan terkait cara menjaga kesehatannya selama menjalani kehamilan di masa pandemi Covid-19, baik berupa tanda gejala, prognosis, cara pengobatan, akses pelayanan yang cepat dan tepat, serta tata cara protokol kesehatan yang harus dipraktikkan dalam kehidupan sehari-hari (Khoramabadi et al., 2015). Dengan memiliki pengetahuan yang baik, ibu hamil juga akan terhindar dari cemas dan stress dalam kehamilan yang dapat mempengaruhi kesehatan ibu dan janin (Ben-Ari et al., 2020).

Sehingga hasil penelitian ini juga memberikan manfaat untuk tatatanan klinik yaitu sangat dibutuhkan edukasi dan pemberian informasi kesehatan secara berksinambungan (Al-Ateeq \& Al-Rusaiess, 2015). Edukasi sebagai sumber pendukung utama pelayanan dan perawatan kesehatan dengan melakukan pendekatan teurapeutik utama bagi ibu hamil terutama jika telah terkonfirmasi positif Covid-19. Disamping upaya untuk menemukan pengobatan dan vaksin sedang sangat intensif sedang dilakukan (Liang \& Acharya, 2020). Walau bagaimanapun, 
pencegahan dan deteksi dini merupakan hal utama yang sepatutnya harus dilalakukan (Mascarenhas et al., 2020).

Pemberian pelayanan yang lebih fokus bagi ibu hamil selama masa pandemi Covid-19 terbukti dapat meningkatkan Kesehatan ibu dan bayi hingga persalinan dengan berbagai konsep baru yang telah dicanangkan (Fryer et al., 2020). Sehingga dalam pemberian informasi terdapat beberapa hal yang diharapkan menjadi perilaku rutin yang lebih spesifik yang harus dibekali untuk ibu hamil agar tetap terhindar dari Novel Corona Virus yaitu; mencuci tangan secara rutin dengan handsanitizer atau sabun, hindari menyentuh bagian mata, hidung dan mulut, menjaga jarak dengan orang lain sekitar satu meter, menutup mulut atau hidung saat bersin dan batuk, menggunakan masker saat berinteraksi dengan orang lain, serta menjaga kebersihan rumah dan sekitar (Nwafor et al., 2020).

Berdasarkan hasil penelitian ini maka sangat disarankan adanya pemberian informasi melalui edukasi Kesehatan oleh tenaga Kesehatan untuk ibu hamil baik di tatatanan klinik maupun di komunitas agar ibu dapat menjalani masa kehamilannya dengan sejahtera walaupun di masa pandemi Covid-19. Peneliti selanjutnya dapat melakukan penelitian lebih lanjut terkait intervensi yang dapat diberikan bagi ibu hamil untuk tetap mempertahankan atau meningkatkan pengetahuan dan perilaku ibu hamil dalam menjalani kehamilan selama masa pandemi.

\section{KESIMPULAN}

Penelitian ini menunjukkan bahwa ada hubungan yang signifikan antara tingkat pengetahuan dengan perilaku ibu dalam menjalani kehamilan selama masa pandemi Covid-19. Terdapat berbagai faktor yang dapat mempengaruhi pengetahuan dan perilaku ibu hamil seperti paritas, sumber informasi, dan perolehan edukasi secara rutin oleh pemberi layanan Kesehatan.

\section{UCAPAN TERIMAKASIH}

Peneliti mengucakan terimakasih kepada seluruh pihak yang terlibat dalam penelitian ini terutama kepada seluruh responden.

\section{DAFTAR PUSTAKA}

Al-Ateeq, M. A., \& Al-Rusaiess, A. A. (2015). Health education during antenatal care: The need for more. In International Journal of Women's Health (Vol. 7, pp. 239-242). https://doi.org/10.2147/IJWH.S75164

Anikwe, C. C., Ogah, C. O., Anikwe, I. H., Okorochukwu, B. C., \& Ikeoha, C. C. (2020). 
Coronavirus disease 2019: Knowledge, attitude, and practice of pregnant women in a tertiary hospital in Abakaliki, southeast Nigeria. Gynecology Obstetrics, 151, 197-202. https://doi.org/10.1002/ijgo.13293

Ben-Ari, O. T., Chasson, M., Sharkia, S. A., \& Weiss, E. (2020). Distress and anxiety associated with COVID-19 among Jewish and Arab pregnant women in Israel. Journal of Reproductive and Infant Psychology, 38(3), 340-348. https://doi.org/https://doi.org/10.1080/02646838.2020.1786037

Fryer, K., Delgado, A., Foti, T., Reid, C. N., \& Marshall, J. (2020). Implementation of Obstetric Telehealth During COVID-19 and Beyond. Maternal and Child Health Journal, 24(9), 1104-1110. https://doi.org/10.1007/s10995-020-02967-7

Hoque, M., \& Hoque, M. E. (2011). Knowledge of danger signs for major obstetric complications among pregnant KwaZulu-Natal women: Implications for health education. Asia-Pacific Journal of Public Health, 23(6), 946-956. https://doi.org/10.1177/1010539511428698

Kementerian Kesehatan RI. (2020). Kesiapsiagaan Menghadapi Infeksi Covid-19. In Kementerian Kesehatan RI. Sekretariat $r$ Jenderal. Rencana Strategis Kementerian Kesehatan Tahun Rencana Strategis Kementerian Kesehatan Tahun (p. 248). https://doi.org/351.077 Ind r

Khan, S., Zeb, F., Shoaib, M., Haq, I. U. L., Xu, K., \& Li, H. (2020). Selected Micronutrients : An Option to Boost Immunity against COVID-19 and Prevent Adverse Pregnancy Outcomes in Pregnant Women : A Narrative Review. Iran Public Health, 49(11), 20322043.

Khoramabadi, M., Dolatian, M., Hajian, S., Zamanian, M., Taheripanah, R., Sheikhan, Z., Mahmoodi, Z., \& Seyedi-Moghadam, A. (2015). Effects of Education Based on Health Belief Model on Dietary Behaviors of Iranian Pregnant Women. In Global journal of health science (Vol. 8, Issue 2, pp. 230-239). http://www.embase.com/search/results?subaction=viewrecord \&from=export\&id=L6158 28714\%0Ahttp://dx.doi.org/10.5539/gjhs.v8n2p230

Liang, H., \& Acharya, G. (2020). Novel corona virus disease ( COVID-19) in pregnancy: What clinical recommendations to follow? 1-4. https://doi.org/10.1111/aogs.13836

Mar'ah, E. M. (2020). Tunaikan Layanan Kesehatan Ibu dan Anak di Masa Pandemi Covid19. Indonesian Journal of Community Health Nursing (Jurnal Keperawatan Komunitas), 5(2), 23-28. https://e-journal.unair.ac.id/IJCHN/article/viewFile/22449/12335

Mascarenhas, V. H. A., Caroci-Becker, A., Venâncio, K. C. M. P., Baraldi, N. G., Durkin, A. C., \& Riesco, M. L. G. (2020). Covid-19 and the production of knowledge regarding recommendations during pregnancy: A scoping review. Revista Latino-Americana de Enfermagem, 28, 1-10. https://doi.org/10.1590/1518-8345.4523.3348

Nwafor, J. I. J. K. A., Okechukwu, B., \& Ikeotuonye, A. C. (2020). Knowledge and practice of preventive measures against COVID-19 infection among pregnant women in a lowresource African setting Johnbosco. https://doi.org/10.1101/2020.04.15.20066894

Samji, P. (2020). Coronavirus Disease (COVID-19) - Risk to Pregnant Women. https://www.bio-services.org/covid-19-pregnancy/

Shing, Y. L., \& Brod, G. (2016). Effects of Prior Knowledge on Memory: Implications for Education. In Mind, Brain, and Education (Vol. 10, Issue 3, pp. 153-161). https://doi.org/10.1111/mbe.12110

WHO. (2020). Coronavirus. https://www.who.int/health-topics/coronavirus\#tab=tab_1 


\section{LAMPIRAN}

Tabel 1. Distribusi data demografi ibu hamil dalam menjalani kehamilan di masa pandemi Covid-19 $(\mathrm{n}=138$ orang)

\begin{tabular}{llll}
\hline No & Data Demografi & Frekwensi & \% \\
\hline $\mathbf{1}$ & Domisili & & \\
& Aceh Utara & 50 & 36,2 \\
& Pidie & 88 & 63,8 \\
\hline \multicolumn{2}{l}{ Total } & 138 & 100 \\
\hline Usia & & \\
& Remaja Akhir & 59 & 42,8 \\
& Dewasa Awal & 79 & 57,2 \\
\hline & Total & 138 & 100 \\
& Paritas & & \\
& Primipara & 70 & 50,7 \\
& Multipara & 68 & 49,3 \\
& & & 100 \\
\hline
\end{tabular}

Sumber: Data Primer (Diolah tahun 2020)

Tabel 2. Distribusi tingkat pengetahuan ibu hamil dalam menjalani kehamilan di masa pandemi Covid-19 $(\mathrm{n}=138$ orang)

\begin{tabular}{llll}
\hline No & Tingkat Pengetahuan & Frekwensi & \% \\
\hline $\mathbf{1}$ & Baik & 70 & 50,7 \\
$\mathbf{2}$ & Kurang Baik & 68 & 49,3 \\
\hline & Total & 138 & 100
\end{tabular}

Sumber: Data Primer (Diolah tahun 2020)

Tabel 3. Distribusi tingkat perilaku ibu hamil dalam menjalani kehamilan di masa pandemi Covid-19 ( $\mathrm{n}=138$

\begin{tabular}{llll}
\hline No & Perilaku & orang) & Frekwensi \\
\hline $\mathbf{1}$ & Baik & 82 & 59,4 \\
$\mathbf{2}$ & Kurang Baik & 56 & 40,6 \\
\hline & Total & 138 & 100 \\
\hline
\end{tabular}

Sumber: Data Primer (Diolah tahun 2020)

Tabel 4. Distribusi hubungan tingkat pengetahuan dengan perilaku ibu hamil dalam menjalani kehamilan di masa pandemi Covid-19 ( $\mathrm{n}=138$ orang)

\section{Pengetahuan}

\begin{tabular}{|c|c|c|c|c|c|c|c|c|}
\hline \multirow[t]{2}{*}{ Perilaku } & \multicolumn{2}{|c|}{ Buruk } & \multicolumn{2}{|c|}{ Baik } & \multicolumn{2}{|c|}{ Total } & \multirow{2}{*}{$\alpha$} & \multirow{2}{*}{ P- Value } \\
\hline & $\mathrm{f}$ & $\%$ & $\mathrm{~F}$ & $\%$ & $\mathrm{f}$ & $\%$ & & \\
\hline Kurang Baik & 38 & 28,4 & 18 & 27,6 & 56 & 56,0 & \multirow{3}{*}{0.05} & \multirow{3}{*}{0,001} \\
\hline Baik & 32 & 41,6 & 50 & 40,4 & 82 & 82,0 & & \\
\hline Total & 70 & 70,0 & 68 & 68,0 & 138 & 138 & & \\
\hline
\end{tabular}

Sumber: Data Primer (Diolah tahun 2020) 